\title{
Isolation and Characterization of Local Isolates of Rhizobia in Nineveh Governorate/Iraq
}

\author{
Ahmed Ali Mohammed ${ }^{1 *}$, Raad Hassani Sultan² \\ ${ }^{1 * 2}$ Department of Biology, Education College for Pure Sciences, University of Mosul, Mosul, Iraq \\ E-mail: ${ }^{1 *}$ Ahmed.esp40@ student.uomosul.edu.iq, ${ }^{2}$ dr.raadsultan@uomosul.edu.iq,
}

(Received May 18, 2021; Accepted June 21, 2021; Available online August 28, 2021)

DOI: 10.33899/edusj.2000.168657, (C) 2021, College of Education for Pure Science, University of Mosul.

This is an open access article under the CC BY 4.0 license (http://creativecommons.org/licenses/by/4.0/).

\begin{abstract}
In this study, thirty-six local isolates of rhizobial bacteria were isolated from root nodes of different leguminous plants collected from different areas in Nineveh Governorate/Iraq. The rhizobial colonies were purified and their agronomic and biochemical characteristics were studied. Results of this study showed that the local isolates had the ability to consume different sugars as a carbon source. Also, the antibiotic sensitivity test showed that only one isolate, Rhizobium leguminosarum bv. phaseoli AS12 was resistant to the antibiotic Azithromycin $15 \mu \mathrm{g} / \mathrm{ml}$, and the isolate Rhizobium leguminosarum bv. phaseoli AS14 showed resistance to the antibiotic Gentamycin $10 \mu \mathrm{g} / \mathrm{ml}$, and the rest of the isolates showed different rates of resistance and sensitivity for the rest of the antibiotics. The local isolates showed different $\mathrm{NaCl}$ tolerance levels up to $8.0 \%$, while no tolerance was observed for Rhizobium leguminosarum bv. viciae AS11 isolate at any of the studied concentrations. Results of heavy metal salt tolerance study showed that the isolates of Ensifer meliloti AS34 and Rhizobium leguminosarum bv. viciae AS36 were sensitive to $\mathrm{ZnSo}_{4}$ at a concentration of $25 \mu \mathrm{g} / \mathrm{ml}$, while the tolerability of the other isolates to the studied heavy salts differed at concentrations higher than $25 \mu \mathrm{g}$ $/ \mathrm{ml}$. All the studied isolates showed a positive result in staining with Congo red and Aniline blue dyes. Maximum exopolysaccharide production was $494 \mathrm{mg} / \mathrm{Li}$ by Rhizobium leguminosarum bv. viciae AS35. Antimicrobial activity test showed maximum inhibition zone $17 \mathrm{~mm}$ by Rhizobium leguminosarum bv. viciae AS36 against Proteus vulgaris.
\end{abstract}

Keyword: rhizobia, characterization, exopolysaccharide, antimicrobial activity

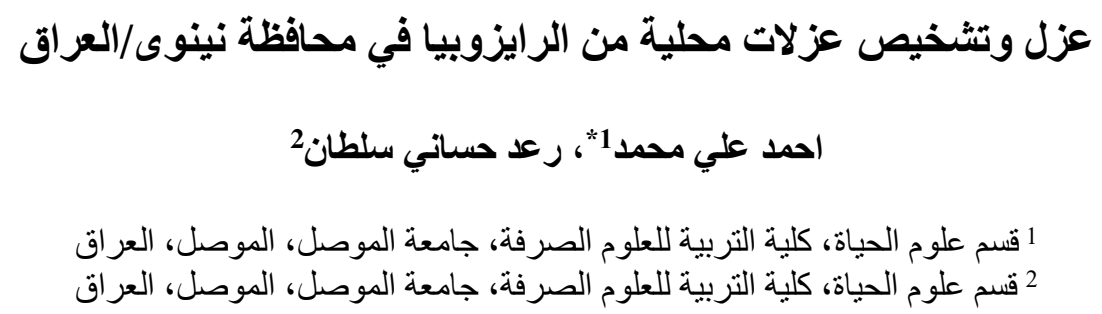

الخلاصة:

تم في هذه الدراسة عزل 36 عزلة رايزوبيا محلية من العقد الجذرية لمختلف النباتات البقولية النامية في مناطق مختلفة لمحافظة نينوى/العراق. تم تنقية المزارع الرايزوبية ودراسة الصفات المزرعية والبايوكيميائية لها. نتائج هذه الدراسة اظهرت قابيلة عزلات الرايزوبيا 
Rhizobium المحلية لاستغلال سكريات مختلفة كمصدر للكاربون. اختبار الحساسية للمضادات الحيوية اظهرت بأن عزلة واحدة هي

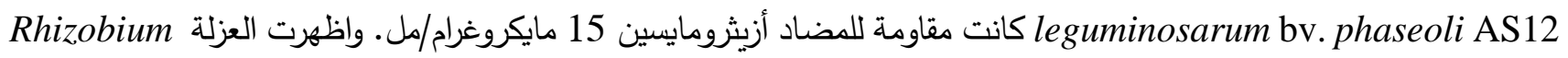
leguminosarum bv. phaseolus AS14 معدلات مختلفة من المقاومة والحساسية تجاه بقية المضادات الحيوية. أظهرت عزلات الرايزوبيا المحلية مستويات تحمل مختلفة من

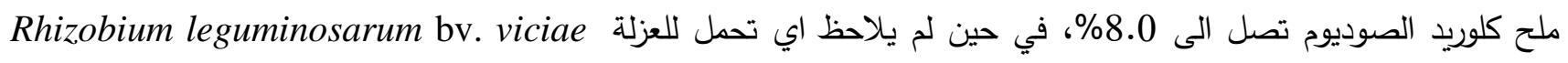

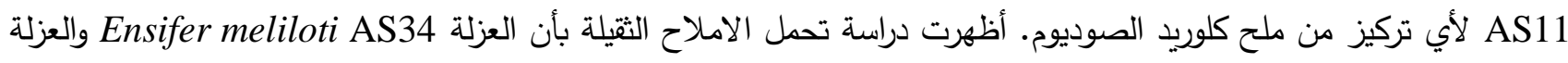

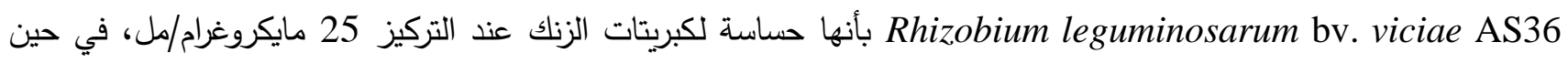

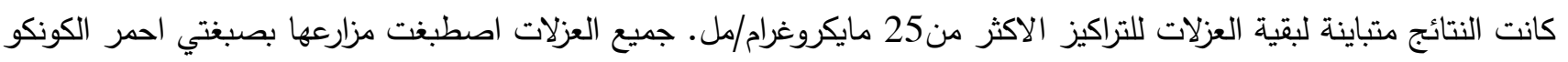

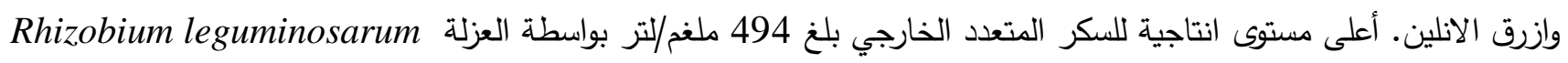

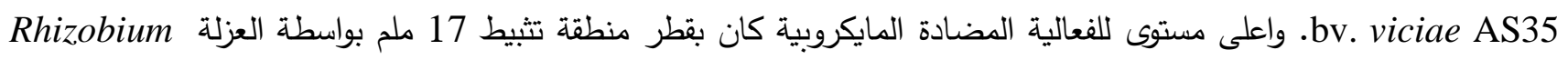

Proteus vulgaris تجاه البكتريا المرضية leguminosarum bv. viciae AS36

$$
\text { الكلمات المفتاحية: رايزوبيا، تثخيص، السكر المتعدد الخارجي، الفعالية المضادة المايكروبية. }
$$

\section{Introduction}

Gaseous nitrogen $\left(\mathrm{N}_{2}\right)$ is abundantly available in the atmosphere. Plants and animals cannot convert it into a biological useful form. Only a few prokaryotes have the ability to utilize the gaseous nitrogen. These organisms reduce the gaseous dinitrogen $\left(\mathrm{N}_{2}\right)$ to ammonia. This process, known as biological nitrogen fixation, is carried out by the enzyme system nitrogenase. Some nitrogen fixing bacteria like Klebsiella pnumoniae, Azotobacter, and Rhodopseudomonas are able to reduce nitrogen into ammonia as free living organisms. Other organisms fix nitrogen only in symbiotic relationship with a eukaryotic host plant, like rhizobia in legume symbiosis, Frankia in actinorhizal symbiosis and Cyanobacteria in Gunnera symbiosis [1]. Symbiotic nitrogen fixation is of great importance to agriculture since it reduces the need of fertilizer nitrogen.

In agriculture, perhaps rhizobia-legume symbiosis contributes as much as $80 \%$ of the biologically fixed nitrogen [2]. The bacteria of genera Rhizobium, Bradyrhizobium, Azorhizobium, Mesorhizobium and Ensifer, collectively called rhizobia, form symbiotic association with leguminous plants. The bacteria induce the formation of specialized structures, called nodules, on the roots of legume plants. The reduction of atmospheric nitrogen takes place in these nodules. The establishment of symbiotic association takes place in several steps like recognition and infection of root hairs, development and differentiation of root nodules, multiplication of rhizobia and their converts into bacteroids within plant cells and conversion of nitrogen to ammonia. Symbiosis also involves uptake and assimilation of energy rich carbon compounds by bacteroids and utilization of fixed nitrogen by plants [3].

Strains of different rhizobial species possess indigenous plasmids. Megaplasmids have been found in Ensifer meliloti strains. Many of the genes, which are important in symbiosis are plasmid borne. In $E$. meliloti genes required for nodulation and nitrogenase activity have been mapped on the megaplasmid pSyma. The second megaplasmid, pSymb carries genes involved in exopolysaccharide synthesis and uptake of various nutrients [4]. Researchers revealed that exopolysaccharide (EPS) are key components for the establishment of an effective symbiosis between leguminous plants and rhizobia [5]. Recently, non-toxic rhizobial EPS have been found to have properties suitable for application in various fields, including medicine [6]. 


\section{Research Method \\ Isolation of rhizobial bacteria from the root nodules of leguminous plants:}

Host leguminous plants were uprooted with an amount of soil and washed. Pink colour nodules were cut with scissors and keeping a small part of the link that connects the nodule to the roots. Root nodules were immersed in physiological solution for several times. Then nodules immersed in ethanol $70 \%$ for 2-4 minutes, after that nodules immersed in sodium hypochloride solution with $3 \%$ concentration for 15 minutes [7], [8]. Washing nodules with normal saline for 3 times and nodules transferred with sterile forceps to a solid TY medium. Incubation for 24 hours were done at $28 \pm 2{ }^{\circ} \mathrm{C}$ to ensuring efficiency of sterilization. After that the root nodules were destroyed under sterile conditions with sterile rod glass in $1 \mathrm{ml}$ of physiological solution. $0.1 \mathrm{ml}$ of different dilutions of bacterial suspensions were spread with glass diffuser on TY agar plates to obtain single pure colonies. Plates were incubated at $28 \pm 2{ }^{\circ} \mathrm{C}$ for $24-48 \mathrm{hrs}$.

\section{Reverse Inoculation Test:}

To insure the bacterial isolated are rhizobia, inoculation of two days' seedlings of leguminous plants were done.

\section{Isolates Maintenance:}

Single colony of each isolates, were streaked on TY slant agar medium and kept in refrigerator 4 ${ }^{\circ} \mathrm{C}$. Reculturing were done each 3-4 weeks.

\section{Media Used in This Study:}

\section{Typtone Yeast Extract Medium:}

This medium was used for growing rhizobial bacteria and prepared by dissolving 5 gm of tryptone, $3 \mathrm{gm}$ of yeast extract, $0.12 \mathrm{gm}$ of $\mathrm{CaCl}_{2} .2 \mathrm{H}_{2} \mathrm{O}$ in $1 \mathrm{Li}$ of distilled water and adjusting pH AT 7.0 [9].

\section{Tryptone Yeast Extract (TY) Swarm Plate Medium:}

This medium was prepared by adding $3 \mathrm{gm} / \mathrm{Li}$ agar to the TY medium. This medium used for motility test.

\section{Yeast Extract Mannitol Medium:}

This medium prepared as follows $(\mathrm{gm} / \mathrm{Li})$ : Yeast Extract, 0.4; Mannitol, 10; $\mathrm{NaCl}, 0.1$; $\mathrm{MgSO}_{4} .7 \mathrm{H}_{2} \mathrm{O}, 0.2$ and $\mathrm{K}_{2} \mathrm{HPO}_{4}, 0.5$ and $\mathrm{pH}$ was adjusted at 6.8 [10].

\section{Rhizobial Minimal Medium:}

This medium was used to recognize the isolates whether suffer from nutritional mutations or not. Compositions of this medium as follows g/Li: $\mathrm{Na}_{2} \mathrm{HPO}_{4} .12 \mathrm{H}_{2} \mathrm{O}, 0.45 ;\left(\mathrm{NH}_{4}\right)_{2} \mathrm{SO}_{4}, 2.0 ; \mathrm{FeCl}_{3}, 2.0$; $\mathrm{MgSO}_{4} .7 \mathrm{H}_{2} \mathrm{O}, 0.1 ; \mathrm{CaCl}_{2} .2 \mathrm{H}_{2} \mathrm{O}, 0.04$ and distilled water to make volume $990 \mathrm{ml}$. The $\mathrm{pH}$ of the medium was adjusted to 7.0 with $0.1 \mathrm{~N} \mathrm{NaOH}$ solution [11].

\section{Muller-Hinton Agar medium:}

This medium was prepared by dissolving $35 \mathrm{gm}$ of the medium in a litter of distilled water and adjusting the $\mathrm{pH}$ at 7.2.

\section{Triple Sugar Iron Agar Medium:}


Preparation of this medium were done by dissolving $65 \mathrm{gm}$ of this medium and complete the size to 1 litter with distilled water. Adjusting $\mathrm{pH}$ at 7.2-7.4 were done.

\section{Gelatin Liquefaction Medium:}

This medium was prepared by dissolving $128 \mathrm{gm}$ of this medium in a litter of distilled water, $\mathrm{pH}$ was adjusted at $7.2[12]$.

\section{Rhizobial Isolates Characterization:}

\section{Cultural and Microscopic Examination:}

Appearance of rhizobial colonies and cultural moisture were examined by necked eye. Gram staining ability and bacterial shape were examined under microscope.

\section{Biochemical Tests:}

\section{Citrate Utilization Test:}

This test was done to determine the capacity of isolates to use various carbohydrate sources e.g. sucrose, glucose and lactose as media for growth. After inoculation and incubation, colour were observed [2].

\section{Gelatin Liquefaction Test:}

This test was carried out by inoculation of gelatin medium with fresh rhizobial colonies by stabbing with inoculum needle and incubated at $28 \pm 2{ }^{\circ} \mathrm{C}$ for $24 \mathrm{hrs}$. Results recorded after half an hour at $4{ }^{\circ} \mathrm{C}$ [13].

\section{Triple Sugar Iron Test:}

This test was performed by inculating the medium with a young of rhizobial bacteria and at $28 \pm 2$ ${ }^{\circ} \mathrm{C}$ for $72 \mathrm{hrs}$. the positive result was recorded by changing the colour of the medium to dark brown colour [14].

\section{Intrinsic Antibiotic Resistance (IAR) Spectra:}

This experiment was carried out to identify sensitivity or resistance of local rhizobial isolates against different antibiotics were used to assay the antibiotic resistance on Millar-Hinton agar plates. Plates containing the discs were incubated at $28 \pm 2{ }^{\circ} \mathrm{C}$ for 3-7 days [2]. The presence or absence of inhibitory zones around different antibiotic discs was noted. Studied antibiotics as follows; Azithromycin, Gentamycin, Vancomycin, Amikacin, Streptomycin and Erythromycin.

\section{Heavy Metal Sensitivity Test:}

To estimate ability of local rhizobial isolates to grow on TY plates containing different concentrations of heavy metal salts, different heavy meatal salts were added to TY plates as follows: $\mathrm{Pb}$ $\left(\mathrm{CH}_{3} \mathrm{COO}\right), \mathrm{COCl}_{2}$ and $\mathrm{HgCl}_{2}$ with concentration $500 \mu \mathrm{g} / \mathrm{ml}$. [15].

\section{Tolerance to Sodium Chloride Salt:}

The salinity tolerance of sodium chloride salt was assayed by culturing the rhizobial bacteria on YEMA medium containing different sodium chloride salt concentration as follows: 1.0, 2.0, 3.0 and 4.0\%, respectively [2]. 


\section{Growth on Rhizobial Minimal Medium:}

This experiment was conducted to find out the ability of isolates to grow on minimal medium. $\mathrm{RMM}$ plates streaked with different young colonies and incubated at $28 \pm 2{ }^{\circ} \mathrm{C}$ for $24-48$ hours. Results recorded depending on the growth of the bacteria [16].

\section{Cell Surface Molecules Production Tests:}

\section{Test for Production of Cellulose Fibrils:}

All local rhizobial isolates were streaked on YEM agar medium containing $0.02 \%(\mathrm{w} / \mathrm{v})$ Congo red. The growth was observed after incubation at $28 \pm 2 \mathrm{C}^{\circ}$ for 3 days. The presence of cellulose fibrils on the surface of rhizobial cells was indicated by production of red colonies [17].

\section{Test for Production of $\beta-(1-3)$ Glucans:}

The taking up of the Aniline Blue dye by the local rhizobial cells of given isolate indicates the ability of this strain to produce $\beta-(1-3)$ glucans [18]. All local isolates were streaked on YEM agar medium containing $0.02 \%(\mathrm{w} / \mathrm{v})$ Aniline Blue. The presence or absence of blue colonies was recorded after incubation at $28 \pm 2 \mathrm{C}^{\circ}$ for 3 days.

\section{Test for Production of $\beta$-(1-2) Glucans:}

The production of $\beta$-(1-2) glucans can be detected on swarm plates [19]. A loop full of cell suspension of each isolates was spotted on TY was done at $28 \pm 2 \mathrm{C}^{\circ}$ for 3 days and spots were examined for swarming after every $24 \mathrm{hrs}$. Swarming indicated the production of $\beta$-(1-2) glucans.

\section{Utilization of Different Sugars:}

Utilization of several sugars (glucose, galactose, arabinose, fructose, maltose, xylose, rhamnose and lactose) by local rhizobial isolates was studied. Each isolate was streaked on RMM agar medium (without glucose) supplemented with different sugars. Incubation was done at $28 \pm 2 \mathrm{C}^{\circ}$ for 5 days and after $48 \mathrm{hrs}$. of incubation bacterial growth was observed daily.

\section{Dry Cell Growth Estimation:}

The rhizobial growth was measured based on the dry weight per volume of the culture. The cell dry weight (CDW) was determined by centrifugation (5000 rpm for $30 \mathrm{~min}$.), followed by drying to a constant weight in an oven at $60{ }^{\circ} \mathrm{C}$ overnight [20].

\section{Exopolysaccharide Estimation:}

For The estimation of EPS production, rhizobial isolates were inoculated into YEM broth medium supplemented with $1.0 \%$ mannitol. Incubation at $28 \pm 2 \mathrm{C}^{\circ}$ at $150 \mathrm{rpm}$ for 2 days. After incubation, the culture broth was centrifuged (5000 rpm for $30 \mathrm{~min}$ ), and the supernatant was mixed with two volumes of acetone. The crude polysaccharide was collected by centrifugation (5000 rpm for $45 \mathrm{~min}$.). The EPS was washed with distilled water and acetone. Then transferred onto a filter overnight at $105{ }^{\circ} \mathrm{C}$ [21].

\section{Antimicrobial Activity Test:}

Well diffusion assay was followed for antimicrobial activity test. Each local rhizobial isolate were grown in TY broth medium at $28 \pm 2 \mathrm{C}^{\circ}$ for $24 \mathrm{hrs}$. Centrifugation at $5000 \mathrm{rpm}$ were done for 15 min. A culture was passed through $0.2 \mathrm{~nm}$ micro filter to get fermented medium without rhizobial 
cells. Muller agar medium plates were prepared and $0.1 \mathrm{ml}$ of each pathogenic bacterial culture were transferred and spreaded. Wells $6 \mathrm{~mm}$ were done and $200 \mu \mathrm{l}$ of each rhizobial filtrated culture were transferred to the wells. Replicates were done as well as a negative control with $100 \mu$ normal saline [22]. The diameter of the inhibition zone was measured with calipers in $\mathrm{mm}$. The antimicrobial activity was determined by measuring the clear zone around the wells.

\section{Results And Discussion}

Roots of different leguminous plants were collected from different areas of Nineveh Governorate/Iraq, and results showed a success of isolating single colonies from smashed nodules after growing on TY plates. The sixty-three different rhizobial isolates and the given names as well as the host plants were recorded in Table 1.

Table 1. Local isolated rhizobia and their hosts.

\begin{tabular}{|l|l|l|}
\hline Isolate No. & Rhizobial genera and species & Host plant \\
\hline $\begin{array}{l}\text { AS1, AS2, AS3, AS5, } \\
\text { AS6, AS24, AS33, AS34 }\end{array}$ & Ensifer meliloti & Medicago sativa L. (Alfalfa) \\
\hline AS4, AS7, AS8, AS9 & Ensifer fredii bv. fredii & Vigna unguiculata L. (Cowpea) \\
\hline AS10 & Mesorhizobium loti & Cicer arietinum L. (Chickpea) \\
\hline AS11 & $\begin{array}{l}\text { Rhizobium leguminosarum } \\
\text { bv. viciae }\end{array}$ & Lens culinaris L. (Lental) \\
\hline $\begin{array}{l}\text { AS12,AS13,AS14, } \\
\text { AS15,AS16,AS17, } \\
\text { AS18,AS19,AS20,AS21 }\end{array}$ & $\begin{array}{l}\text { Rhizobium leguminosarum } \\
\text { bv. phaseoli }\end{array}$ & Phaseolus vulgsris L. (Green bean) \\
\hline $\begin{array}{l}\text { AS22, AS23, AS25, } \\
\text { AS26, AS27, AS28, } \\
\text { AS29, AS30, AS31, } \\
\text { AS32, AS35, AS36 }\end{array}$ & $\begin{array}{l}\text { Rhizobium leguminosarum } \\
\text { bv. viciae }\end{array}$ & Viciae faba L. (Broad) \\
\hline \multicolumn{1}{|c|}{ A } & \\
\hline
\end{tabular}

A success of isolation of different local rhizobial isolates were also recorded by many researchers $[2,13,23]$.

\section{Reverse Inoculation Test:}

Reverse inoculation test study revealed ability of all the thirty-six rhizobial isolates were able to induce root nodules on their specific leguminous plants confirming the success symbiotic relations with their specific leguminous host.

\section{Cultural and Microscopic Examination:}

On the basis of morphological characteristics, the isolates were circular in shape with entire margin and milky to watery translucent appearance on TY agar medium. It was found that the colonies of the local rhizobial strains grown showed the convex elevation in Yeast Extract Mannitol. Gram's staining of the isolates was confirmed by microscopic observations and the isolates was found to be Gram negative and rod shaped. Gauri et al., [24] also reported that microscopic examinations of Rhizobium showed that the isolates to be Gram negative. Roychowghury et al. [25] observed his strain under microscopic by Gram staining which showed pinkish colour and red shaped bacteria.

\section{Biochemical Tests:}

Results revealed that all the local rhizobial isolates could utilize citrate. Wani and Khan [26] and Gauri et al. [23] also reported that Mesorhizobium isolates were positive for citrate utilization. All the 
isolated rhizobial local strains showed positive results for gelatin liquefaction test with exception with isolates: AS2, AS3, AS4, AS10 and AS11 were unable to liquefaction of gelatin. Kumari et al. [27] also reported different results with variant rhizobial isolates and mentioned that gelatinase enzyme plays an important role during nodule formation. Only one strain AS11 was negative for Triple Sugar Iron test. The variation in enzymatic activities of rhizobial isolates was reported by various workers. It is reported that Rhizobium isolates wich produce these enzymes are considered as best for nodulation and nitrogen fixation [27].

\section{Intrinsic Antibiotic Resistance (IAR) Spectra:}

Antibiotic sensitivity study showed that only one isolate i. e., Rhizobium leguminosarum bv. phaseoli AS12 was resistant to Azithromycin $15 \mu \mathrm{g} / \mathrm{ml}$ and the isolate Rhizobium leguminosarum bv. phaseoli AS14 showed resistance to the Gentamycin $10 \mu \mathrm{g} / \mathrm{ml}$, whereas the other isolates showed different resistance and sensitivity patterns. An IAR spectrum is used for the identification of nodulating strains in reports intended to assess the ecological competitiveness. Kucuk and Kivanc [28] found great variation among chickpea rhizobia with respect to their IAR pattern.

\section{Heavy Metal Salts Tolerance:}

Results of tolerance of heavy metal showed that the isolates Ensifer meliloti AS34 and Rhizobium leguminosarum bv. viciae AS36 were sensitive to $\mathrm{ZnSO} 4$ at a concentration of $25 \mu \mathrm{g} / \mathrm{ml}$, whereas the tolerability of the other isolates was different at concentration higher than $25 \mu \mathrm{g} / \mathrm{ml}$. Datta et al. [29] investigated the effect of metal ions on Rhizobium strains observed that all the strains were sensitive to mercuric chloride.

\section{Tolerance to Sodium Chloride Salt:}

All local rhizobial isolates showed good and very good tolerance up to $4.0 \%$ of sodium chloride salt with exception with Rhizobium leguminosarum bv. viciae AS11, which was unable to tolerate even $1.0 \%$ of sodium chloride salt. Increase salt concertation's up to $4.0 \%$ led to moderate rhizobial growth, anyhow no growth was found with isolates AS3, AS10 with sodium chloride concentration 8.0\%. Wadhwa et al. [2] found that rhizobial bacteria differ in their capability of sodium chloride salt tolerance. Research showed that some strains may grow at salt concentrations as high as $500 \mathrm{mM} \mathrm{NaCl}$, others may not grow even at low $\mathrm{NaCl}$ concentration [28].

\section{Growth on Rhizobial Minimal Medium:}

Study of growth of local rhizobial isolates on RMM showed ability of these bacteria to grow on the mentioned medium indicted that these isolates doesn't suffered from any nutritional mutations [16].

\section{Production of Cell Surface Molecules Test:}

Results of production of cell surface molecules test revealed ability of local rhizobial isolates to uptake Congo Red and Aniline Blue dyes indicating of production of cellulose fibrils and $\beta-(1-3)$ glucans. Aniline Blue is known to specifically bind to the curdlan type of polysaccharide, of which beta-(1-3) is a major component [17], [18]. The cell surface molecules are very necessary for rhizobia-legume symbiosis [30]. Clear swarming for each plate spotted with certain local rhizobial isolate gave a good proof for production of $\beta-(1-2)$ glucans. Absence of beta-(1-2) glucans has been linked to a defective flagellum and resulting absence of chemotactic response which in turn leads to formation of ineffective nodules [19]. 


\section{Utilization of Different Sugars:}

Results of utilization of different studied sugars ability of isolated rhizobia to utilize different sugars viz., glucose, galactose, arabinose, fructose, maltose, xylose, rhamnose and lactose. This results agree with results of Hossain et al. [30], which results revealed that ability of tow rhizobial strains RhBC and NRA1 to utilize different sugars.

\section{Production of Exopolysaccharide:}

A cording to examination of rhizobial culture mucoid mixture by necked eye, ten rhizobial isolates were chosen for production of exopolysaccharide production study. These isolates as follows: AS6, AS8, AS10, AS11, AS18, AS21, AS26, AS32, AS35 and AS36. Table 2 shows the mean values of final $\mathrm{pH}$, cell dry weight.

\begin{tabular}{|c|c|c|c|}
\hline Isolate No. & Final $\mathrm{pH}$ & CDW $(\mathrm{mg} / \mathrm{Li})$ & EPS $(\mathrm{mg} / \mathrm{Li})$ \\
\hline AS6 & $6.19 \pm(0.09)^{*}$ & $350 \pm(0.53)$ & $175 \pm(0.22)$ \\
\hline AS8 & $6.23 \pm(0.16)$ & $630 \pm(0.21)$ & $239 \pm(0.18)$ \\
\hline AS10 & $6.13 \pm(0.44)$ & $210 \pm(0.10)$ & $318 \pm(0.12)$ \\
\hline AS11 & $6.89 \pm(0.52)$ & $770 \pm(0.22)$ & $236 \pm(0.09)$ \\
\hline AS18 & $6.15 \pm(0.61)$ & $350 \pm(0.17)$ & $182 \pm(0.11)$ \\
\hline AS21 & $6.14 \pm(0.21)$ & $350 \pm(0.23)$ & $158 \pm(0.17)$ \\
\hline AS26 & $5.54 \pm(0.14)$ & $490 \pm(0.18)$ & $299 \pm(0.09)$ \\
\hline AS32 & $5.60 \pm(0.11)$ & $420 \pm(0.15)$ & $237 \pm(0.11)$ \\
\hline AS35 & $5.01 \pm(0.41)$ & $280 \pm(0.19)$ & $494 \pm(0.23)$ \\
\hline AS36 & $4.84 \pm(0.23)$ & $350 \pm(0.10)$ & $166 \pm(0.15)$ \\
\hline
\end{tabular}

* Each value presents triplicates, values between brackets presents S.D.

Maximum mean value exopolysaccharide production was by the isolate AS35 which was 494 $\mathrm{mg} / \mathrm{Li}$. Minimum production was by the isolate AS21 which mean value was $158 \mathrm{mg} / \mathrm{Li}$. Ghosh et al. [31] study revealed that the maximum EPS production by Rhizobium sp. was $765 \mathrm{mg} / \mathrm{Li}$ when they used mannitol as a carbon source. Prabhavati and Malliah [32] research results showed that mannitol gave productivity $4690 \mathrm{mg} / \mathrm{Li}$ by Rhizobium $\mathrm{sp}$.

\section{Antimicrobial Activity Test:}

After adding $200 \mu \mathrm{l}$ of fermented filtrate medium, results showed differences in inhibition zone diameter. A maximum average inhibition zone was $17 \mathrm{~mm}$ by Rhizobium leguminosarum bv. viciae AS36 against Proteus vulgaris. Average of inhibition zone was $15 \mathrm{~mm}$ by Ensifer meliloti against Proteus mirabilis and Proteus vulgaris, respectively. Fig. 1and 2 shows effect of rhizobial fermented filtrate broth on growth of studied pathogenic bacteria. Joseph et al. [33] results study revealed that Rhizobium leguminosarum bv. trifolii produce bacteriocin-like substances and have antimicrobial activity against Salmonella typhi A and B, Pseudomonas aeruginosa, Staphylococcus citrus and Proteus vulgaris. Inhibition zone were 5, 6, 8, 6, 7 and $8 \mathrm{~mm}$, respectively. Deora and Singh [34] research results revealed that rhizobia isolated from Vigna radiate have antimicrobial activity against E. coli and Staphylococcus aureus, which inhibition zone diameter ranged from 13 to $15 \mathrm{~mm}$. Antimicrobial activity of Rhizobium japonicum and Bradyrhizobium japonicum were recorded and the zone of inhibition (in mm) was 8.3 for Aspergillus niger, 7.4 for Fusarium oxysporum and 8 for Alternaria alternata from Rhizobium japonicum and for Bradyrhizobium japonicum the zone of 
inhibition was 9.2 for Apegillus niger, 7.6 for Fusarium oxysporum and 8.5 for Alternaria alternata [23].

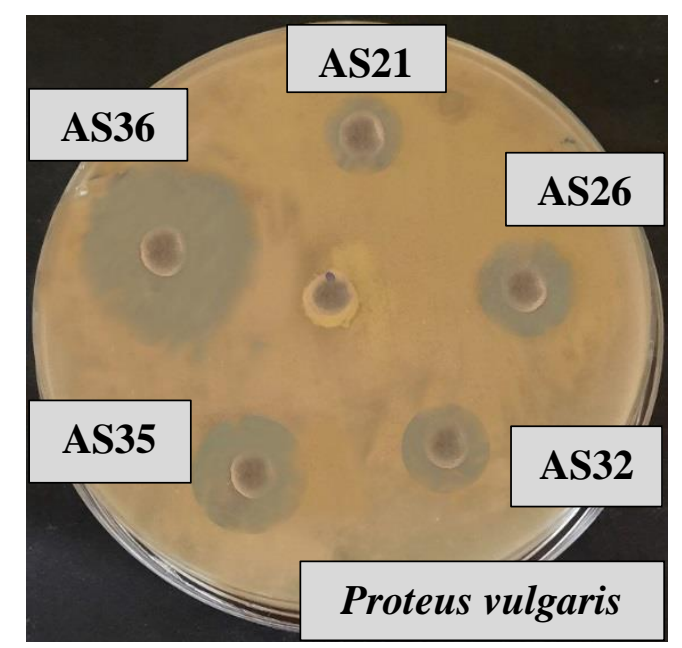

Figure 1: Shows effect of Rhizobium leguminosarum bv. viciae AS36 fermented broth medium filtrate against Proteus vulgaris (17 mm inhibition zone). In the plate center is a negative control well $(200 \mu$ l normal saline).
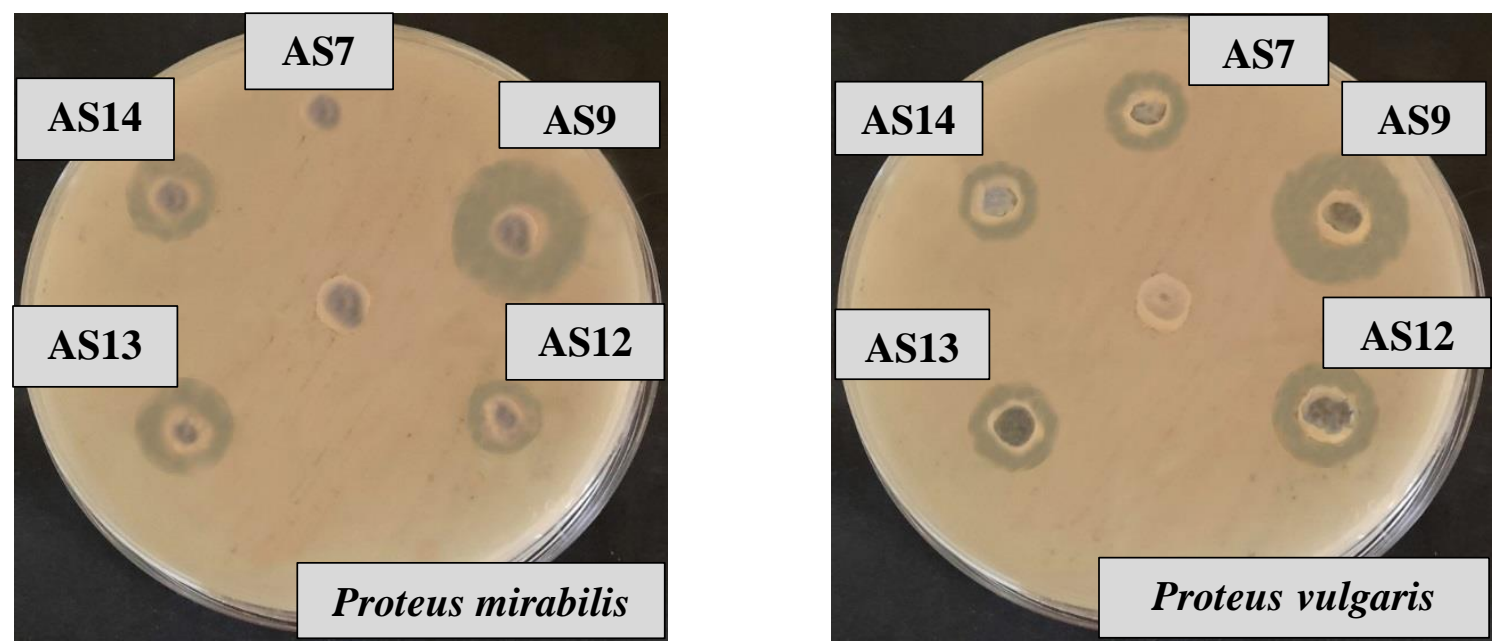

Figure 2: Shows effect of Ensifer fredii bv. fredii AS9 fermented broth medium filtrate against Proteus mirabilis (Left) and Proteus vulgaris (Rhight) (15 mm inhibition zone). In the plate center is a negative control well (200 $\mu 1$ normal saline).

\section{Conclusion}

This research work showed ability of isolation of a local Rhzobial isolates that produce exopolysaccharide and some of a local isolates exhibited antimicrobial activity against of studied bacterial pathogens. We recommend that expand the area of isolation may give much more results.

\section{Acknowledgements}


The authors are grateful to the University of Mosul/ College of Education for Pure Sciences for their provided facilities, which helped to improve the quality of this work.

\section{References}

[1] A. Van Kammen,. The molecular development of nitrogen fixing root nodules. In Nitrogen Fixation Fundamentals and Application. I.A. Tikhonovich et al. (eds), pp. 9-149 Kluwer Academic Publishers, Netherlards, 1995.

[2] Z. Wadhwa; V. Srivastava; R. Rani; Tanvi, K. Makkar and S. Jangra. Isolation and characterization of Rhizobium from Chickpea (Cicer arietinum). Int. J. Curr. Microbiol. Appl. Sci., 6(11): 2880-2893, 2017.

[3] R. Hassani, C.K. Prrsad, K.E. Vinetha, N. Vis; P. Singh, S. Yadav, and G.S. Randhawa. Isolation and Synbiotic Characterization of Isolecine+ Valine and Lancine anxotrophs of Sinorhizobium. India J Exp. Biol., 40(10): 1110-1120, 2002.

[4] F.D. Barloy-Huber, M.J. Capela; S. Barnett; N.A. Kalman; S.R. Feberspiel and F. Gilbert. High-resolution Phycical map of the Sinorhizobium meliloti 1021 pSyma Mega. J. Bacteriol, 182:1185-1189, 2000.

[5] L. G. Castellani, A. Luchetti; J.F. Nilssom, J. P. Perez- Gimenez, C. Wegenener; A. Schluter; A. Puhler, A. Lagares; S. Brom; M. Pistoria; K. Niehaus and G.A.T. Tejerizo. Exopolysaccharide Characterization of Rhizobium Favelukesii LPU83 and its rolet in the symbiosis with alfalfa. Front. Plant Sci., 12:1-17, 2021.

[6] T.C.L. Castellane; B.F.S. de Sonsa and E.G.M. Lemos. Exopolysaccharide product for industry and environment. Curr. Appl. Poly. Sci., 3:157-166, 2019.

[7] J.M. Vincent. Nitrogen Fixation in Legumes. Academic Press, London, U.K, 1982.

[8] A. Petit; J. Stongaard; A. Kuhle; K.A. Marker and J. Tempe. Transformation and regeneration of Legume Lotus corniculates: A system for molecular studies of symbiotic nitrogen fixation. Mol. Gen. Genet.; 207:245-250, 1987.

[9] S.P.S. Khannja and S. Kumar. Isolation of phage for Rhizobium meliloti AK631. Indian J. Exp. Biol., 26:665-667, 1988.

[10] J. M. Vincent. Manual for the Practical Study of Root-Nodule Bacteria, pp:164 Blackwell Scientific Publications, Oxford. U.K, 1970.

[11] A. Singh; J. Ram; V. A. Sikka and S. Kumar. Derivation of marked strains in Rhizobium leguminosarum R1d1 by nitrosoguanidine and transposon mutagenesis. Indian J. Exp. Biol., 22: 239-247, 1984.

[12] J. G. Colle; B. P. Marmion; A. G. Fraser and A. Simmons. Practical Medical Biology. Mackie and McCarteny, Chrchill Livingston, p. 263-98, New Youk, USA, 1996.

[13] K. R. Aneja. Experiments in Microbiology Plant Pathology and Biotechnology, $4^{\text {th }}$ edition, New Age International Publishers, New Delhi, India, 2003. 
[14] N. N. B. Kumari; B. Nagrraju and K. Mallikarjuna. Biochemical characterization and protein profile by sodium dodecyl sulphate-polyacrylamide gel electrophoresis of French bean (Phaseolus vulgaris L.) associated rhizobia. Innovare J. Agri. Sci., 6(1): 8-13, 2018.

[15] L. Rubio-Sanz; B. Brito and J. Palacios. Analysis of metal tolerance in Rhizobium leguminosarum strains isolated from ultramafic soil. FEMS Microbiol., 365(4): 1-7, 2018.

[16] C. K. Prasad; K. E. Vineetha; R. Hassani; R. Gupta and G. S. Randhawa. Isolation and symbiotic characterization of aromatic amino acid auxotrophs of Sinorhizobium meliloti. Indian J. Exp. Biol., 38: 1041-1049, 2000.

[17] B. E. Kneen and T. A. La Rue. Congo red absorption by Rhizobium leguminosarum. Appl. Environ. Microbial., 45: 423-427, 1983.

[18] I. Nikanishi; K. Kimura; T. Suzuki; M. Ishakawa; I. Banno; T. Sakane and T. Harada. Demonstration of curdlan type polysaccharides and some other beta (1-3) glucan in microorganism with aniline blue. J. Gen. Appl. Microbiol., 22: 1-11, 1976.

[19] R. A. Geremia; S. Cavaignac; A. Zorrequieta; N. Toro; J. Olivars and R. A. Ugalde. A Rhizobium meliloti mutant that forms ineffective pseudonodules in alfalfa produce exopolysaccharides but fails to form $\beta$-(1-2) glucans. J. Bacteriol., 169: 880-884, 1987.

[20] T. C. L. Castellane; M. V. F. Lemos and E. G. M. Lemos. Evaluation of the biotechnological potential of Rhizobium tropici strains for exopolysaccharide production. Carbohyd. Poly., 111: 191-197, 2014.

[21] B. S. Kumari; M. R. Ram and K. V. Malliah. Studies on exopolysaccharide and indole acetic acid production by Rhizobium strains from Indigofera. Afri. J. Microbiol., Res., 3(1): 010-014, 2009.

[22] I. Kalalou; M. Faid and A. T. Ahami. Extending shelf of fresh minced camel meat at ambient temperature by Lactobacillus dlbrueckii subsp. delbrueckii. Elctro. J. Biotechnol., 7(3): 243248, 2004.

[23] R. G. Nandi; J. K. Bara and P. Shrivastava. Antimicrobial activity of Rhizobium japonicum and Bradyrhizobium japonicum on different plant pathogenic fungal strains. Microbio. Commum., 12(2): 435-439, 2019.

[24] Gauri, A. K. Singh and M. Bamania. Characterization of Mesorhizobium sp. Isolated from root nodules of Cicer arietinum. Int. J. Agri. Res., 2: 142-154, 2012.

[25] D. Roychowdhury; M. Paul and S. K. Banerjee. Isolation, identification and characterization of bacteria (Rhizobium) from chick pea (Cicer arietinum) and production of biofertilizer. Eur. J. Biotech. Biosci., 3(12): 26-29, 2015.

[26] P. A. Wani and M. S. Khan. Isolation of multiple metal and antibiotic resistant Mesorhizobium sp. And their plant growth promoting activity. Res. J. Microbiol., 8: 25-35, 2013.

[27] B. S. Kumari; M. R. Ram and K. V. Mallaiah. Studies on nodulation, biochemical analysis and protein profiles of Rhizobium isolated from Indigofera species. Malaysian J. Microbiol., 6(2): 133-139, 2010. 
[28] C. Kucuk and M. Kivanc. Preliminary characterization of Rhizobium strains isolated from chickpea nodules. Afr. J. Biotechnol., 7: 772-775, 2008.

[29] A. Datta, R.K. Singh and S. Kumar. Isolation, characterization and growth of Rhizobium strains under optimum conditions for effective biofertilizer production. Int. J. Pharm. Sci. Rev. Res. 32(1), 199-208, 2015.

[30] A. Hossain; S. K. Gunri; M. Barman; A. El Sabah; J. A. T. da Silva. Isolation, Characterization and purification of Rhizobium strain to enrich the productivity of groundnut (Arachis hypogaea L.). Open Agricul., 4: 400-409, 2019.

[31] A. C. Ghosh and P. S. Basu. Production of extracellular polysaccharide by a Rhizobium species from root nodules of the leguminous tree Dalbergia lanceolara. Eng. Life Sci., 5(4): 378-382, 2005.

[32] E. Prabhavati and K. V. Mallaiah,. Extracellular polysaccharide production by Rhizobium sp. nodulating Macrotyloma uniflorum (Lam.) Verdc. Asian J. Bio. Sci., 4(1): 20-23, 2009.

[33] M. V. Joseph; J. D. Desai and A. J. Desai. Production of antimicrobial and bacteriocin-like substances by Rhizobium trifolii. Appl. Environ. Microbiol., 45(2): 532-535, 1983.

[34] G. S. Deora and K. Singhal. Isolation, biochemical characterization and preparation of biofertilizers using Rhizobium strains for commercial use. Biotech. Res. Comm., 3(2): 132136, 2010. 